\title{
KARAKTERISTIK PANGAN FUNGSIONAL NUGET DAN STIK DARI TEPUNG IKAN LAYANG EKOR MERAH (Decapterus kuroides) DAN AMPAS TAHU
}

\author{
Marni Kaimudin, Sumarsana, Mozes Sukur Yodida Radiena, Sugeng Hadi Noto \\ Balai Riset dan Standardisasi Industri Ambon, Jalan Kebun Cengkeh (Batu Merah Atas) 97128 Ambon \\ Diterima: 7 Agustus 2021/Disetujui: 29 Desember 2021 \\ *Korespondensi : marnikaimudin72@gmail.com
}

Cara sitasi: Kaimudin M, Sumarsana, Radiena MSY, Noto SH. 2021. Karakteristik pangan fungsional nuget dan stik dari tepung ikan layang ekor merah (Decapterus kuroides) dan ampas tahu. Jurnal Pengolahan Hasil Perikanan Indonesia. 24(3): 370-380.

\begin{abstract}
Abstrak
Potensi sumber daya ikan layang ekor merah (Decapterus kuroides) dan ampas tahu yang melimpah dan belum dimanfaatkan secara maksimal merupakan aset untuk ekonomi kerakyatan dengan membuat tepung alternatif sebagai bahan substituen pangan olahan fungsional berbahan dasar tepung terigu misalnya nuget dan stik. Upaya eksternal yang bernilai guna terhadap olahan pangan fungsional, dilakukan penelitian bertujuan untuk mengetahui karakteristik nuget dan stik berbahan dasar tepung ikan layang ekor merah dan ampas tahu. Metode penelitian yang digunakan yaitu deskriptif kualitatif. Perlakuan penelitian adalah perbandingan antara tepung ikan, tepung ampas tahu dan tepung terigu dengan rasio 1:1:1, 1:2:3, 1:3:2, 2:1:3 2:3:1, 3:1:2, 3:2:1. Parameter uji produk nuget meliputi sensori (aroma, rasa, tekstur), kadar air, abu, lemak, protein, timbel (Pb), coliform, E.coli, Salmonella, Staphylococcus aureus dan produk stik meliputi sensori (bau, warna, rasa, kenampakan), kadar air, abu, lemak, protein, kalsium, timbel dan kapang. Hasil penelitian menunjukkan pada rasio bahan 3:1:2 menghasilkan nuget dan stik dengan karakteristik terbaik. Karkteristik nuget dengan nilai sensori aroma 5,96, rasa 6,13 dan tekstur 5,96, kadar air 41,59\%, abu 2,32\%, protein 21,67\%, lemak 14,08\%, timbel $<0,073 \mathrm{mg} / \mathrm{kg}$, coliform $<3 \mathrm{MPN} / \mathrm{g}$, E.coli $<3 \mathrm{MPN} / \mathrm{g}$, Salmonella negatif/25 g, Staphylococcus aureus negatif. Karakteristik stik dengan nilai sensori bau 4,70, tekstur 4,57, rasa 4,52 dan kenampakan 4,57 , serta kadar air $22,87 \%$, abu 5,22\%, protein $15,11 \%$, lemak $17,36 \%$, kalsium $25,7 \mathrm{mg} / \mathrm{kg}$, timbel $<0,073 \mathrm{mg} / \mathrm{kg}$, kapang $5 \mathrm{koloni} / \mathrm{g}$. Hasil karakteristik nuget dan stik sesuai SNI 01-66822000, SNI 7587:2013 dan Peraturan BPOM No.16 tahun 2016.
\end{abstract}

Kata kunci : ikan layang ekor merah, karakteristik mutu, limbah tahu, produk olahan, tepung alternatif

\section{Characteristics of Functional Food of Nugget and Stick Based on Redtail Scad (Decapterus kurroides) Flour and Tofu Dregs}

\begin{abstract}
The potential resources of redtail scad (Decapterus kuroides) and tofu dregs which are abundant and have not been utilized optimally are assets for the people's economy by making alternative flour as a substituent for functional processed food made from wheat flour such as nuggets and sticks. An external effort that is useful for functional food processing, a study was carried out aimed at knowing the characteristics of nuggets and sticks made from red tail scad flour and tofu dregs. The research method used is descriptive qualitative. The research treatment was the ratio between fish meal, tofu pulp flour and wheat flour with a ratio of 1:1:1, 1:2:3, 1:3:2, 2:1:3 2:3:1, 3:1:2 , 3:2:1. Nuggets product test parameters include sensory (aroma, taste, texture), water content, ash, fat, protein, lead, coliform, E.coli, Salmonella, Staphylococcus aureus and stick products include sensory (smell, color, taste, appearance), moisture content, ash, fat, protein, calcium, lead, mold. The results showed that the 3:1:2 ratio of ingredients produced nuggets and sticks with the best characteristics. Characteristics of nuggets with a sensory value of 5.96 flavor, 6.13 taste and 5.96 texture, as well as $41.59 \%$ moisture, $2.32 \%$ ash, $21.67 \%$ protein, $14.08 \%$ fat, lead $<0.073 \mathrm{mg} / \mathrm{kg}$, coliform $<3 \mathrm{MPN} / \mathrm{g}$, E.coli $<3 \mathrm{MPN} / \mathrm{g}$, Salmonella negative/25g, Staphylococcus aureus negative. Characteristics of the stick with a sensory score value of 4.70 smell, 4.57 texture, 4.52 flavour and 4.57 appearance, $22.87 \%$ moisture, $5.22 \%$ ash, $15.11 \%$ protein, $17.36 \%$ fat, $25.7 \mathrm{mg} / \mathrm{kg}$ calcium, lead $<0.073 \mathrm{mg} / \mathrm{kg}$, mold 5 colony $/ \mathrm{g}$. The characteristics of nugget and stick are in accordance with SNI 01-6682-2000, SNI 7587:2013 and BPOM Regulation No.16 of 2016.
\end{abstract}

Keywords: alternative flour, processed products, quality characteristics, redtail scad, tofu waste 


\section{PENDAHULUAN}

Kebutuhan tepung terigu saat ini kian meningkat seiring dengan perkembangan bisnis kuliner yang menjamur, termasuk penggunaannya sebagai bahan dasar olahan pangan fungsional (Anonim 2021). Untuk mengurangi ketergantungan terhadap tepung terigu perlu dikembangkan penggunaan tepung alternatif lain pada pengolahan pangan fungsional. Tepung alternatif yang dapat digunakan di antaranya adalah tepung dari ikan layang ekor merah (Decapterus kuroides) dan ampas tahu.

Potensi ikan layang ekor merah sebesar 24.133 ton (Direktorat Jenderal Perikanan Tangkap 2014). Akibatnya, jenis ikan ini menjadi limbah yang berdampak bagi estetika lingkungan. Jenis ikan layang ekor merah kurang disukai karena selain rasa dagingnya yang hambar, ikan ini sangat cepat busuk. Pemanfaatan ikan layang hanya sebagai pakan dan umpan untuk hiu. Untuk meningkatkan nilai ekonomis, ikan layang ekor merah diolah menjadi tepung ikan.

Cilia et al. (2016) melaporkan bahwa tepung ikan layang memiliki kandungan protein $63,75 \%$, lemak $6,93 \%$, kadar air 9,69\%, kadar abu 9,37\%, serat kasar 5,03\% dan bahan ekstrak tanpa nitrogen (BETN) 5,23\%.

Potensi ampas tahu hasil survei terhadap pengusaha tahu di daerah pasar Batu Merah Ambon sebesar 80 ton/tahun (Juhairi 2018). Isu ampas tahu sebagai limbah yang berdampak terhadap pencemaran lingkungan dapat dicegah dengan memanfaatkannya (Ismanto et al. 2013).

Ampas tahu mengandung zat gizi antara lain $8,33 \%$ kadar air, $21,70 \%$ protein, $11,95 \%$ serat dan 2,89\% abu (Kaahoao et al. 2014), 41,3\% karbohidrat (Daftar Komposisi Bahan Makanan 1992), $29 \mathrm{mg}$ fosfor, $19 \mathrm{mg}$ kalsium, dan $4 \mathrm{mg}$ besi (Mahmud et al. 2009). Selama ini ampas tahu dimanfaatkan untuk pakan. Olahan pangan ampas tahu adalah dengan membuatnya menjadi tepung.

Tepung ampas tahu mengandung $66,24 \%$ karbohidrat, $17,72 \%$ protein, $3,23 \%$ serat kasar dan 2,62\% lemak (Wati dan Rahma 2013). Kandungan tepung terigu yaitu $74,48 \%$ karbohidrat, $9,61 \%$ protein, $1,95 \%$ lemak dan 0,4-0,5\% serat kasar (Fransiska dan Deglas 2017). Dalam Daftar Komposisi Bahan Makanan (Direktorat Gizi Depkes RI, 2015), kandungan zat gizi ampas tahu yaitu terkandung 26,6\% protein, 18,3\% lemak dan $41,3 \%$ karbohidrat.

Ketersediaan bahan baku yang besar dan kandungan gizi yang tinggi merupakan alasan mengapa kedua jenis tepung tersebut berpotensi sebagai tepung alternatif untuk menggantikan tepung terigu dan berpotensi sebagai bahan dasar pangan fungsional.

Pangan fungsional merupakan pangan dengan kandungan komponen aktif yang dapat memberikan manfaat bagi kesehatan, selain manfaat yang diberikan oleh zat-zat gizi yang terkandung di dalamnya (Astawan 2011). Sesuai pernyatan Badan POM (Suter 2013) bahwa pangan fungsional secara alamiah maupun telah melalui proses, mengandung satu atau lebih senyawa yang dianggap mempunyai fungsi-fungsi fisiologis yang bermanfaat bagi kesehatan dan tidak memberikan kontraindikasi dan efek samping pada jumlah penggunaan yang dianjurkan terhadap metabolisme zat gizi lainnya. Produk pangan fungsional yang telah dikenal luas antara lain dapat berupa nuget dan stik yang cukup favorit dikalangan masyarakat terutama kelompok umur anak-anak (Rifqi 2012; Yulianan 2020).

Nuget merupakan produk olahan daging atau protein hewani dengan tahap digiling, dibumbui, diselimuti perekat tepung, pelumuran tepung roti (breading) dan digoreng setengah matang lalu dibekukan (Permadi et al. 2012).

Stik merupakan produk camilan atau makanan ringan yang berbentuk panjang, pipih menyerupai tongkat. Berbahan utama tepung terigu dengan proses penggorengan (Galih 2014), bersifat ringan, tidak mengenyangkan dan umumnya disajikan saat istirahat tanpa atau dengan minuman (Kristiastuti dan Afifah 2013).

Perkembangan penelitian pemanfaatan tepung ikan dan ampas tahu untuk produk pangan olahan seperti nuget dan stik yang telah dilakukan dan mempunyai peluang untuk dikembangkan karena memiliki sifat pangan fungsional yang signifikan terhadap manusia, antara lain; formula dan kualitas 
nuget ikan rinuak (Yuliana 2020), uji kualitas kimia dan organoleptik pada nuget ayam hasil substitusi ampas tahu (Putri dan Nita 2018), karakteristik kimia dan organoleptik kue stik ampas tahu (Fransiska dan Deglas 2017), pengaruh substitusi tepung ampas tahu dalam pembuatan nuget terhadap kadar protein dan daya terima konsumen (Sari 2012), pemanfaatan tepung daging ikan layang untuk pembuatan stik ikan (Pratiwi et al. 2013), karakteristik kimia dan sesnsori nuget ikan patin Pangasius sp.-ampas tahu dengan pewarna buah bit (Beta vulgaris) (Rosselinda 2018), pengaruh penambahan ikan kembung terhadap organoleptik dan kadar air nuget ampas tahu (Widiada et al. 2016).

Nuget dan stik yang dibuat menggunakan ampas tahu dan tepung ikan sebagai substituen dalam pembuatan biaya produksinya menjadi lebih rendah (Handarsari et al. 2010; Putri dan Nita 2018). Berdasarkan hasil penelitian tersebut, maka dilakukan penelitian dengan tujuan untuk mengetahui karakteristik nuget dan stik berbahan dasar tepung ikan layang ekor merah dan ampas tahu.

\section{BAHAN DAN METODE Bahan dan Alat}

Bahan utama yang digunakan adalah ikan layang ekor merah (Decapterus kuroides) yang diperoleh dari pasar mardika Ambon dan ampas tahu dari pengrajin tahu Batu Merah Ambon (Maluku). Bahan bantu yang digunakan meliputi bahan bantu proses antara lain; tepung panir, minyak kelapa,

Table 1 Comparison rasio of redtail scad (Decapterus kuroides) flour, tofu dregs flour and flour.

\begin{tabular}{cccc}
\hline Formulation & $\begin{array}{c}\text { Redtail } \\
\text { scad } \\
\text { flour }\end{array}$ & $\begin{array}{c}\text { Tofu } \\
\text { dregs } \\
\text { flour }\end{array}$ & Flour \\
\hline A & 1 & 1 & 1 \\
B & 1 & 2 & 3 \\
C & 1 & 3 & 2 \\
D & 2 & 1 & 3 \\
E & 2 & 3 & 1 \\
F & 3 & 1 & 2 \\
G & 3 & 2 & 1 \\
\hline
\end{tabular}

bawang putih bubuk, merica bubuk, telur, garam, penyedap Royco dan bahan bantu analisis yaitu buffer peptonwater (BPW), plate count agar (PCA), potatoes dextrose agar (PDA), lactose broth, Ec. broth, bird parker agar, selenite broth, tetrathionate broth, XLD, BSA, SSA, HE, NA, lysin, MR-VP, agar urea, TSIA, akuades.

Peralatan yang digunakan meliputi peralatan untuk proses masak, molen merek Atlas Marcato-Italia, alat press dan peralatan analisis antara lain; kertas saring, labu lemak datar, erlenmeyer, kapas, kertas saring kasar, neraca analitik, cawan Petri, penggaris $30 \mathrm{~cm}$, tabung reaksi $20 \mathrm{~mL}$ bertutup, rak tabung, pengaduk, beker gelas, botol scott, spiritus, lempeng hangat (hot plate), pipet volumetrik, oven (Memmert UN-110-Jerman), alat cacah koloni, tanur (Nabertherm-Jerman), desikator, kjeltek master (Buchi K-375Swiss), kompor destruksi, buret, inkubator (Memmert-Jerman), autoklaf (Tomy SS-325Jepang), isomantel, soxhlet, penangas air (Memmert-Jerman) dan UV-VIS (Shimadzu UV-2450-Jepang).

\section{Metode Penelitian}

Metode penelitian yaitu deskriptif kualitatif dengan dua kali ulangan. Substitusi tepung ikan layang ekor merah dan tepung ampas tahu terhadap tepung terigu dengan rasio ditunjukkan pada Table 1 .

Tepung ikan layang ekor merah dan ampas tahu yang digunakan adalah hasil olahan sendiri dengan nilai kadar air 4,54\%, abu $1,75 \%$, lemak $6,28 \%$, protein $85,6 \%$, karbohidrat $1,83 \%$ untuk tepung ikan sedangkan tepung ampas tahu memiliki nilai kadar air 8,62\%, abu 3,05\%, lemak 16,55\%, protein $48,12 \%$ dan karbohidrat sebesar $23,66 \%$. Tepung terigu merek Kompas memiliki kadar zat besi sebesar $6,16 \mathrm{mg}$, seng sebesar 4,86 mg, vitamin B1 sebesar 0,50 mg, vitamin $\mathrm{B} 2$ sebesar $0,45 \mathrm{mg}$ dan asam folat sebesar $322 \mathrm{mg}$.

\section{Pembuatan tepung ikan layang ekor merah.}

Ikan layang ekor merah dikeluarkan isi perutnya, dicuci, direbus dalam air mendidih menggunakan panci stainless steel ukuran 20 
$\mathrm{cm}$ selama \pm 5 menit, ditiriskan, dikeringkan dengan oven $80^{\circ} \mathrm{C}$ selama \pm 9 jam, dihaluskan dengan blender dan lolos 100 mesh dan dikemas dalam plastik sealer AA $14 \times 30 \mathrm{~cm}$ sebelum digunakan.

\section{Pembuatan tepung ampas tahu}

Ampas tahu dari pengrajin tahu Batu Merah Ambon dibersihkan dengan cara penyemprotan dengan air dan dipisahkan kotoran-kotoran yang menempel di dalamnya, dikeringkan dengan oven $80^{\circ} \mathrm{C}$ selama \pm 6 jam dan dikemas dalam plastik sealer AA 14x30 $\mathrm{cm}$ sebelum digunakan.

\section{Pembuatan nuget dan stik}

Pembuatan nuget mengacu Yuliana et al. (2018) termodifikasi. Semua bahan sesuai perlakuan dicampur dengan tangan dalam masing-masing baskom hingga homogen. Setelah itu air es ditambahkan sebanyak 200 $\mathrm{mL}$, dicampur hingga adonan kalis, kemudian dibentuk atau cetak dalam loyang berukuran $22 \times 21 \times 6 \mathrm{~cm}$ setinggi $1 \mathrm{~cm}$ menggunakan penggaris. Kemudian nuget dikukus selama $15-20 \mathrm{~cm}$ dengan panci kukus berukuran $20 \mathrm{~cm}$. Setelah itu nuget didinginkan dan dipotong-potong berukuran $5 \times 2 \times 1 \mathrm{~cm}$, dipress, dikemas dalam plastik 16x24 cm.

Pembuatan stik berdasar Lekahena (2019) yang termodifikasi. Bahan utama dicampur dengan bahan tambahan berupa bawang putih $10 \mathrm{~g}$, merica $2 \mathrm{~g}$, seledri $5 \mathrm{~g}$, garam $0,5 \mathrm{~g}$, gula $10 \mathrm{~g}$, margarin cair $30 \mathrm{~g}$, dan telur 2 butir hingga merata, kemudian ditambahkan 200 $\mathrm{mL}$ air es sambil terus diaduk dengan tangan hingga adonan merata, kalis dan tidak lengket di tangan. Adonan dicetak menggunakan cetakan molen-atlanta marcato dengan ukuran $8 \times 1 \times 1 \mathrm{~cm}$, digoreng dengan wajan 28 $\mathrm{cm}$, ditiriskan hingga dingin, kemudian di kemas menggunakan plastik 16x24 cm.

\section{Pengujian}

Karakteristik nuget berdasar SNI 7758:2013 meliputi evaluasi sensori (aroma, rasa, dan tekstur), kadar air, kadar abu, protein, lemak, timbel, coliform, E.coli, Salmonella, Staphylococcus aureus.

Karakterisasi stik terdiri atas evaluasi sensori dan karakteristik kimia.
Evaluasi sensori menggunakan uji mutu hedonik meliputi atribut: bau, tekstur, rasa dan kenampakan menggunakan lembaran uji sensori (SNI 01-2346-2006). Karakteristik kimia menggunakan analisis proksimat lengkap meliputi kadar air (SNI 01-2354.22006) menggunakan metode gravimetik; kadar abu (SNI 01-2354.1-2006); protein metode mikro abu Kjeldahl (SNI 01-2354.42006) dan kadar lemak total metode lemak soxhlet (SNI 01-2354.3.2006), kalsium, dan timbel (SNI 7387:2009), serta kapang.

\section{HASIL DAN PEMBAHASAN}

Hasil penelitian menunjukkan bahwa karakteristik sensori nuget (Table 2) dan stik (Table 3) terbaik pada perlakuan $\mathrm{F}(3: 1: 2)$. Sensori nuget untuk skor aroma, rasa, dan tekstur berturut-turut adalah 5,96; 6,13; 5,96 (Figure 1). Sensori stik untuk skor bau, tekstur, rasa, dan kenampakan berturut-turut adalah 4,70; 4,57; 4,52; 4,57 (Figure 2).

Hasil sensori nuget dan stik dari tepung ikan layang ekor merah dan ampas tahu yang disubstitusi masih diterima konsumen sesuai SNI 7758:2013 untuk nuget dan SNI 01-28862000 untuk stik.

Sejalan dengan hasil evaluasi produk makanan yang diberikan perlakuan khusus menurut Vaclavik dan Christian (2014) terhadap uji organoleptik atau yang biasa dikenal dengan pengujian sensori yang sebelumnya telah dikemukakan oleh BarbosaCanovas tahun 2009 dalam Lekahena (2019) bahwa kriteria penentuan kualitas suatu produk terhadap daya terima konsumen adalah sensori pangan.

Hasil karakterisasi kadar air tertinggi nuget pada rasio $\mathrm{C}(1: 3: 2)$ sebesar $42,99 \%$ dan terendah pada rasio $\mathrm{E}(2: 3: 1)$ sebesar $35,38 \%$. Kadar air tertinggi stik pada rasio $\mathrm{D}(2: 1: 3)$ sebesar 4,87\%, dan terendah pada rasio F(3:1:2) sebesar 3,32\%. Perbedaan hasil kadar air nuget dan stik disebabkan proses pada pengukusan, penggorengan, pengeringan dan rasio penambahan tepung ikan, ampas tahu, dan tepung terigu. Air bebas yang terdapat dalam bahan akan menguap sewaktu penggorengan. Hal ini disebabkan air bebas yang terdapat dalam bahan langsung diuapkan oleh panas wajan dan minyak sebagai media 
Table 2 Characteristics of nugget from redtail scad flour, tofu dregs flour and wheat flour

\begin{tabular}{|c|c|c|c|c|c|c|c|c|}
\hline \multirow{2}{*}{ Parameter } & \multicolumn{7}{|c|}{ Formulation } & \multirow{2}{*}{$\begin{array}{c}\text { SNI } \\
\text { Standard }\end{array}$} \\
\hline & A & $\mathrm{B}$ & $\mathrm{C}$ & $\mathrm{D}$ & E & $\mathrm{F}$ & G & \\
\hline Sensory & & & & & & & & $\begin{array}{c}\text { Min } 7 \\
\text { (Score 3-9) }\end{array}$ \\
\hline Flavour & 4.52 & 4.78 & 4.52 & 2.91 & 4.61 & 5.96 & 3.52 & \\
\hline Taste & 4.78 & 3.91 & 4.83 & 4.52 & 3.70 & 6.13 & 4.30 & \\
\hline Texture & 3.57 & 4.39 & 2.96 & 4.00 & 4.65 & 5.96 & 4.26 & \\
\hline Moisture (\%) & 40.46 & 40.18 & 42.99 & 41.38 & 35.38 & 41.59 & 41.18 & Max. 60 \\
\hline Ash (\%) & 2.33 & 1.92 & 2.40 & 2.56 & 3.17 & 2.32 & 2.47 & Max. 2.5 \\
\hline Protein(\%) & 18.32 & 18.08 & 12.11 & 20.53 & 17.99 & 21.67 & 20.32 & Min. 5 \\
\hline Fat(\%) & 17.69 & 20.70 & 20.04 & 15.91 & 17.70 & 14.08 & 20.03 & Max. 15 \\
\hline Lead(\%) & $<0.07$ & $<0.07$ & $<0.07$ & $<0.07$ & $<0.07$ & $<0.07$ & $<0.07$ & Max. 0.3 \\
\hline Coliform(colony/g) & $<3.00$ & $<3.00$ & $<3.00$ & $<3.00$ & $<3.00$ & $<3.00$ & $<3.00$ & \\
\hline E.coli(colony/g) & $<3.00$ & $<3.00$ & $<3.00$ & $<3.00$ & $<3.00$ & $<3.00$ & $<3.00$ & $<3$ \\
\hline Salmonella (-/25g) & - & - & - & - & - & - & - & $-/ 25 \mathrm{~g}$ \\
\hline $\begin{array}{l}\text { Staphylococcus aureus } \\
\text { (colony/g) }\end{array}$ & 0.00 & 0.00 & 0.00 & 0.00 & 0.00 & 0.00 & 0.00 & Max. $1 \times 10^{2}$ \\
\hline
\end{tabular}

Note: ratio of redtail scad: tofu dregs:wheat flour; $A=1: 1: 1, B=1: 2: 3, C=1: 3: 2, D=2: 1: 3, E=2: 3: 1, F=3: 1: 2, G=3: 2: 1$

Table 3 Characteristics of stick from redtail scad flour, tofu dregs flour and wheat flour

\begin{tabular}{|c|c|c|c|c|c|c|c|c|}
\hline \multirow{2}{*}{ Parameter } & \multicolumn{7}{|c|}{ Formulation } & \multirow{2}{*}{$\begin{array}{c}\text { SNI } \\
\text { Standard }\end{array}$} \\
\hline & A & B & $\mathrm{C}$ & $\mathrm{D}$ & $\mathrm{E}$ & $\mathrm{F}$ & G & \\
\hline Scent & 4.22 & 4.78 & 4.39 & 3.00 & 3.61 & 4.70 & 3.43 & Normal \\
\hline Texture & 4.22 & 3.57 & 4.35 & 4.30 & 4.52 & 4.57 & 4.09 & Normal \\
\hline Flavour & 4.78 & 3.83 & 4.78 & 4.35 & 3.13 & 4.52 & 4.35 & Normal \\
\hline Appearance & 3.57 & 4.39 & 4.39 & 4.09 & 3.65 & 4.57 & 3.74 & Normal \\
\hline Moisture (\%) & 4.51 & 4.26 & 4.66 & 4.87 & 4.80 & 3.32 & 4.10 & Max.4 \\
\hline Ash (\%) & 2.05 & 2.72 & 2.03 & 3.67 & 3.83 & 5.22 & 4.37 & \\
\hline Protein(\%) & 15.75 & 14.36 & 13.22 & 16.38 & 17.70 & 15.11 & 15.33 & \\
\hline Fat(\%) & 14.62 & 10.68 & 10.46 & 12.50 & 12.07 & 17.36 & 13.23 & Max. 38 \\
\hline Calcium (mg/kg) & 120.14 & 61.37 & 138.32 & 246.83 & 182.46 & 256.17 & 241.82 & \\
\hline Lead (mg/kg) & $<0.07$ & $<0.07$ & $<0.07$ & $<0.07$ & $<0.07$ & $<0.07$ & $<0.07$ & Max.1 \\
\hline Mold (colony/g) & $1.20 \times 10^{0}$ & $4.40 \times 10^{1}$ & $1.80 \times 10^{1}$ & $1.40 \times 10^{1}$ & $4.00 \times 10^{0}$ & $5.00 \times 10^{0}$ & $5.00 \times 10^{0}$ & Max.50 \\
\hline
\end{tabular}

Note: ratio of redtail scad: tofu dregs:wheat flour; $\mathrm{A}=1: 1: 1, \mathrm{~B}=1: 2: 3, \mathrm{C}=1: 3: 2, \mathrm{D}=2: 1: 3, \mathrm{E}=2: 3: 1, \mathrm{~F}=3: 1: 2, \mathrm{G}=3: 2: 1$

perantara, sehingga sebagian air bebas yang terdapat dalam jaringan bahan dapat menguap atau berkurang. Kadar air nuget lebih tinggi dibandingkan dari stik disebabkan nuget dibuat dengan pengukusan, sedangkan stik dengan proses penggorengan.

Sebagaimana yang dikemukakan oleh Fransiska dan Deglas, (2017) bahwa tingginya kadar air pada bahan pangan dipengaruhi oleh proporsi tepung terigu. Semakin banyak tepung terigu yang digunakan maka kandungan air yang diperoleh pada nuget dan stik yang dihasilkan juga semakin besar. Rasio berbahan tepung terigu lebih, pada proses pencampuran dan pengadukan (pengulenan) adonan akan lebih mudah diadon dan 


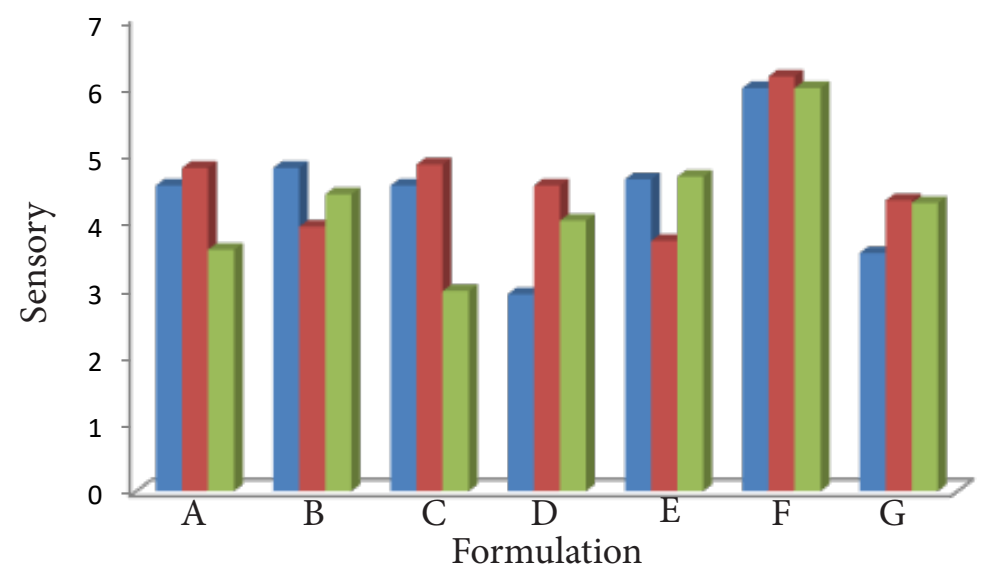

Figure 1 Sensory of nugget from redtail scad flour, tofu dregs flour and wheat flour; ratio of redtail scad: tofu dregs:wheat flour $A=1: 1: 1, B=1: 2: 3, C=1: 3: 2, D=2: 1: 3, E=2: 3: 1, F=3: 1: 2$, $\mathrm{G}=3: 2: 1$; flavour; $\square$ taste; texture.

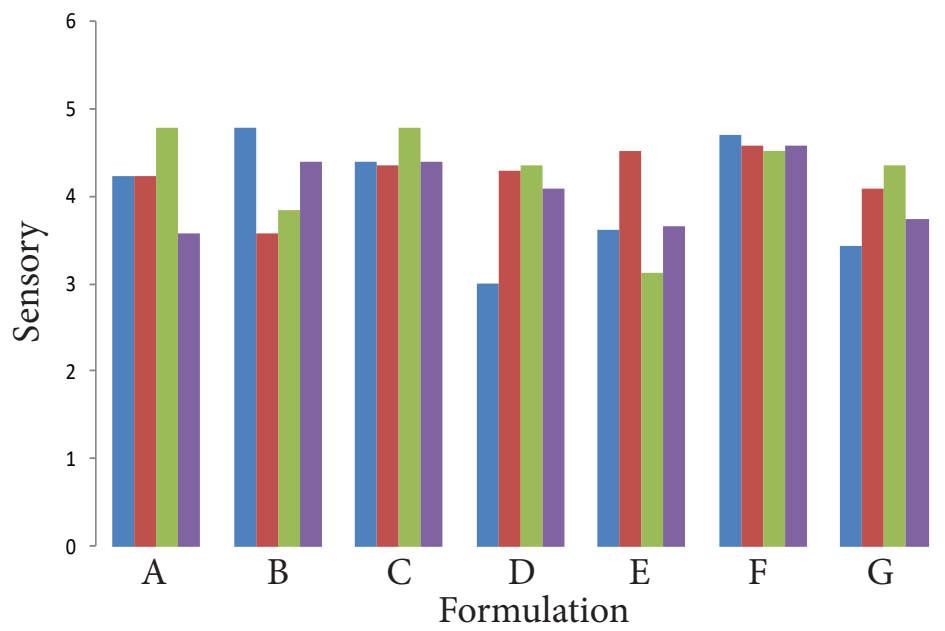

Figure 2 Sensory of stick from redtail scad flour, tofu dregs flour and wheat flour; ratio of redtail scad: tofu dregs:wheat flour $A=1: 1: 1, B=1: 2: 3, C=1: 3: 2, D=2: 1: 3, E=2: 3: 1, F=3: 1: 2$, $\mathrm{G}=3: 2: 1$; aroma; $\square$ texture; $\square$ flavour; $\square$ appearance.

dibentuk karena kadar air tepung terigu tinggi sehingga adonan lebih mudah menyatu.

Hasil karakterisasi kadar abu nuget berkisar $1,92-3,17 \%$. Kadar abu stik berkisar 2,03-5,22\%. Tingginya kadar abu lebih dipengaruhi oleh proporsi tepung ikan layang ekor merah dan ampas tahu yang digunakan. Semakin banyak tepung ikan layang ekor merah dan ampas tahu yang diformulasikan maka kadar abu yang diperoleh juga semakin besar. Hal ini karena tepung ikan layang ekor merah dan ampas tahu mengandung kadar abu yang tinggi dengan nilai kadar abu tepung ikan layang ekor merah sebesar 9,37\% (Cilia et al. 2016) dan abu tepung ampas tahu sebesar 17,03 \% (Wati dan Rahma 2010) dibanding kadar abu tepung terigu sebesar 0,7\% (Mahmud et al. 2009).

Proses pengukusan nuget dan penggorengan stik, menyebabkan mineralmineral yang terkandung dalam produk semakin menurun. Menurut Aldes et al. (2011) bahwa kadar abu menunjukkan oksida logam dan mineral yang terdapat pada suatu bahan. Tingginya kadar abu suatu bahan mengindikasikan tingginya kandungan oksida logam dan mineral yang terdapat dalam bahan tersebut. Abu yang terbentuk merupakan oksida-oksida logam atau logam yang terbakar. 
Hasil karakterisasi kadar protein nuget berkisar 12,11-21,67\%. Kadar protein stik berkisar 13,22-17,70\%. Tinggi rendahnya kadar protein lebih dipengaruhi oleh proporsi tepung ikan dan ampas tahu. Semakin tinggi konsentrasi penambahan tepung ikan dan ampas tahu yang diberikan maka semakin tinggi pula kadar protein nuget dan stik yang dihasilkan.

Tingginya kadar protein pada perlakuan $\mathrm{F}(3: 1: 2)$ diakibatkan oleh penambahan tepung ikan yang lebih banyak dibandingkan tepung ampas tahu dan tepung terigu. Penambahan tepung ikan yang berlebih ini mengakibatkan tingginya kadar protein pada nuget dan stik dan mengakibatkan warna stik menjadi gelap (cokelat tua). Akibat lain dari penambahan tepung ikan yang berlebih pada perlakuan $\mathrm{F}(3: 1: 2)$ juga mengakibatkan terjadinya reaksi Mailard saat penggorengan stik.

Reaksi Mailard adalah reaksi pencokelatan non enzimatis yang terjadi karena adanya reaksi antara gula pereduksi dengan gugus amin bebas dari asam amino atau protein. (Surya et al. 2008)

Yusuf (2011) melaporkan bahwa perubahan warna dari produk pangan misalnya stik akan mengalami perubahan warna menjadi gelap atau cokelat tua disebabkan oleh terjadinya reaksi Mailard yang sangat cepat karena pemanasan di atas titik cair produk pada hasil perikanan misalnya ikan dan udang.

Inarest et al. (2014) melaporkan bahwa kandungan protein produk yang masih belum memenuhi standar SNI diduga karena telah terjadi denaturasi protein pada saat proses pembuatan nuget. Denaturasi adalah proses perubahan molekul protein tanpa menyebabkan rusaknya ikatan peptida (Sumardjo 2009). Denaturasi protein dapat terjadi dengan berbagai cara yaitu oleh panas, $\mathrm{pH}$, bahan kimia, mekanik dan sebagainya. Dalam kasus ini denaturasi dapat diakibatkan oleh panas yang timbul pada saat proses penggilingan dan pemasakan. Protein yang mengalami denaturasi berdampak pada peningkatan daya cerna protein. Oleh karenanya dilakukan proses pengolahan terbaik agar protein tidak mudah rusak dan mudah diserap tubuh adalah menggunakan suhu tinggi dan dalam waktu yang singkat. Hal ini sesuai dengan proses pembuatan nuget yaitu pengukusan dalam waktu singkat (15 menit) dan penggorengan dengan waktu 1-3 menit sehingga protein yang terdapat pada nuget memiliki daya cerna tinggi.

Sefa dan Agyr (2004) melaporkan bahwa semakin lama waktu pengukusan akan mengakibatkan kadar protein semakin tinggi. Selain itu perlakuan pemanasan tidak akan menyebabkan kehilangan protein pada produk. Protein yang terdenaturasi oleh panas akan tetap terukur sebagai protein pada saat pengukuran.

Sejalan dengan hasil penelitian Hanifa et al. (2013) bahwa kadar protein tepung yang digunakan dalam adonan dapat memengaruhi kadar protein produk akhir. Hal ini disebabkan adanya penggunaan tepung terigu dengan kadar protein 9,61\% yang lebih rendah dibandingkan kadar protein tepung ikan layang $63,75 \%$ dan tepung ampas tahu sebesar $17,72 \%$.

Hasil karakterisasi kadar lemak nuget berkisar 14,48-47,54\%. Kadar lemak stik berkisar 10,46-17,36\%. Kadar lemak nuget lebih tinggi dibandingkan dengan stik. Kadar lemak stik menurun setelah melalui proses penggorengan. Kandungan lemak yang terdapat dalam bahan akan terurai dalam minyak goreng. Berbeda dengan nuget yang diproses dengan pengukusan. Pengukusan merupakan salah satu metode pemasakan yang disarankan untuk pengolahan produk. Pengukusan tidak meningkatkan kadar lemak pada bahan makanan sehingga aman dikonsumsi. Sehingga semakin lama pengukusan, ikatan yang terbentuk akan semakin kuat dan padat yang mengakibatkan lemak terperangkap pada produk (Paramita dan Putri 2015).

Noonan dan Savage (1999) yang menyatakan bahwa amilosa merupakan komponen dari pati yang lebih banyak memerangkap komponen seperti air dan lemak ketika terjadi proses pengukusan atau proses yang melibatkan panas. 
Hasil karakteristik kimia nuget dan stik terhadap rasio penggunaan tepung ikan layang ekor merah, ampas tahu dan tepung terigu dengan uji Annova dengan perolehan nilai $\mathrm{F}_{\text {hitung }}(3,16)<\mathrm{F}_{\text {tabel }}(22,7)$ untuk nuget dan $\mathrm{F}_{\text {hitung }}(3,16)<\mathrm{F}_{\text {tabel }}(14,4)$ untuk stik yang menunjukkan bahwa produk nuget dan stik dengan rasio penggunaan bahan tepung ikan layang ekor merah, ampas tahu dan tepung terigu dapat diterima.

Batas kandungan logam berat pada produk nuget dan stik berdasarkan Standar Nasional Indonesia (SNI 7387:2009) mengacu pada batas maksimum cemaran logam berat timbel $(\mathrm{Pb})$ dalam ikan dan produk perikanan adalah maksimum $0,3 \mathrm{mg} / \mathrm{kg}$.

Hasil karakteristik kandungan timbel $(\mathrm{Pb})$ nuget dan stik adalah $<0,073$ sehingga memenuhi persyaratan yang ditetapkan SNI 7387:2009.

Kandungan timbel produk menandakan bahwa bahan pencemar telah terdapat dalam bahan baku. Ningrum (2018) menyatakan bahwa bahan pencemar yang masuk ke dalam perairan akan mengalami tiga proses yaitu proses fisika, kimia, dan biologi. Proses masuknya bahan pencemar secara fisika dan kimia yaitu dengan cara absorbsi dan pengendapan, sedangkan proses biologi dengan cara diserap oleh ikan atau ganggang.

Hasil karakteristik logam menunjukkan bahwa kandungan kalsium stik berkisar 61,37$256,17 \mathrm{mg} / \mathrm{kg}$ sesuai persyaratan hasil SNI 7387:2009. Kalsium adalah mineral penting yang paling banyak dibutuhkan oleh manusia. Kalsium bermanfaat untuk membantu proses pembentukan tulang dan gigi serta diperlukan dalam pembekuan darah, kontraksi otot, transmisi sinyal pada sel saraf. Kalsium dapat membantu mencegah terjadinya osteoporosis. Kalsium dapat berperan dalam menurunkan tekanan darah serta dapat untuk mengurangi resiko terkena penyakit kardiovaskular pada wanita pascamenopause.

Hasil karakteristik mikrobiologi untuk produk nuget dan stik menunjukkan bahwa kedua produk tergolong masih aman, untuk nuget dengan hasil analisis coliform sebesar $<3$, E.coli sebesar $<3$, Salmonella negatif $/ 25 \mathrm{~g}$ dan Staphylococcus aureus negatif sesuai dengan SNI 01-6682-2002, sedangkan untuk produk stik dengan jumlah kapang berkisar $1,20 \times 10^{0}-4,4 \times 10^{1} \mathrm{koloni} / \mathrm{g}$ telah memenuhi SNI 01-2886-2000 dengan batas maksimum kapang 50 koloni/g.

Hasil kapang perlakuan $\mathrm{D}(2: 1: 3)$ sebesar $1,40 \times 10^{1}$ lebih besar dari perlakuan $\mathrm{F}(3: 1: 2)$ dan G(3:2:1) sebesar 5,00 × $10^{\circ} \mathrm{koloni} / \mathrm{g}$. Hal ini terkait dari bahan dasar pembuatan stik dengan penambahan tepung ampas tahu dengan kandungan karbohidrat sebesar $23,66 \%$, kadar air 8,62\% dan lemak 16,55\% yang memungkinkan cepat tumbuhnya kapang.

Sejalan dengan pendapat Gagan (2010) yang menyatakan bahwa jenis mikroba perusak pada umumnya tergantung pada sifat bahan pertanian itu sendiri. Bila bahan pertanian tersebut banyak mengandung pektin, pati atau selulosa, maka hasil pertanian tersebut mudah dirusak oleh kapang. Hasil perolehan kadar air yang semakin tinggi, maka semakin tinggi pula kapang yang dihasilkan. Semakin tinggi kandungan lemak bahan mengakibatkan cepat tumbuhnya mikroba perusak di antaranya adalah kapang.

Hasil karakteristik mikrobiologi stik yang diperoleh juga memenuhi peraturan kepala BPOM No.16 Tahun 2016 bahwa kriteria mikrobiologi untuk produk stik parameter kapang sebesar $10^{4}$ dan untuk produk nuget parameter coliform sebesar $<3$ APM/g, E.coli sebesar $<3$ APM/g, Salmonella negatif/25 g dan Staphylococcus aureus sebesar $10^{3}$.

Karakteristik nuget dan stik yang diperoleh dengan pemanfaatan ikan layang ekor merah dan ampas tahu dengan rasio bahan terbaik $\mathrm{F}(3: 1: 2)$, menunjukkan bahwa bahan baku ikan dan limbah ampas tahu dapat ditingkatkan nilai ekonominya dengan diversifikasi pangan olahan berupa nuget dan stik sebagai pangan fungsional yang dikenal sebagai makanan jajanan masyarakat.

\section{KESIMPULAN}

Tepung ikan layang ekor merah dan ampas tahu dapat dimanfaatkan sebagai tepung alternatif olahan pangan fungsional berupa nuget dan stik dengan rasio bahan terbaik pada 3:1:2 dengan karakteristik yang mengandung satu atau lebih senyawa yang dianggap mempunyai fungsi-fungsi fisiologis 
yang bermanfaat bagi kesehatan dan aman dikonsumsi sesuai SNI 01-6682-2000, SNI 7587:2013 dan Peraturan BPOM No.16 tahun 2016.

\section{UCAPAN TERIMAKASIH}

Terima kasih penulis sampaikan kepada Baristand Industri Ambon dan semua pihak yang telah mendukung dan memberikan bantuan serta kerjasamanya sehingga penelitian ini dapat terlaksana dengan baik.

\section{DAFTAR PUSTAKA}

Aldes L, Yusuf S, Melviana RAM, 2011. Karakteristik kitin dan kitosan dari cangkang kepiting bakau (Scylla serrata). Jurnal Penelitian Sains. 14(3C) 14307.

Anonim. 2018. Harga jual berbagai jenis tepung terigu. https://www.google.com/ search?client $=$ firefox $-b$-d $\checkmark q=$ harga + jual+tepung+terigu+protein + tinggi

Astawan M. 2011. Pangan fungsional untuk kesehatan yang optimal. [Skripsi]. Bogor (ID): Fakultas Teknologi Pertanian IPB, Bogor.

Badan POM. 2016. Kriteria mikrobiologi dalam pangan olahan. Peraturan BPOM 2016-16.

Barbosa-Canovas GV. 2009. Food Engineering Vol. II. Food Texture-Sensory Evaluation. Costell E, Duran L. Encyclopedia of Life Support System. EOLLS Publisher co. Ltd. Oxford UK.

[BSN] Badan Standardisasi Nasional. 2000. Makanan ringan ekstrudat. SNI 01-28862002. ICS.67.180. 20. Jakarta(ID): Badan Standardisasi Nasional Indonesia.

[BSN] Badan Standardisasi Nasional. 2002. Nugget Ayam. SNI 01-66832002. Jakarta(ID): Badan Standardisasi Nasional Indonesia.

[BSN] Badan Standardisasi Nasional. 2006. Cara uji kimia bagian 4: Penentuan kadar protein dengan metode total nitrogen pada produk perikanan. SNI: 01-2354.42006. ICS. 67.120.30 Jakarta(ID): Badan Standardisasi Nasional Indonesia.

[BSN] Badan Standardisasi Nasional. 2006. Petunjuk pengujian organoleptik dan sensorik. SNI 01-2346-2006. Jakarta(ID): Badan Standardisasi Nasional Indonesia.
[BSN] Badan Standardisasi Nasional. 2006. Cara uji kimia bagian 1: Penentuan kadar abu pada produk perikanan. SNI 012354.1-2006. ICS. 67.120.30 Jakarta(ID): Badan Standardisasi Nasional Indonesia..

[BSN] Badan Standardisasi Nasional. 2006. Cara uji kimia Bagian 2: Penentuan kadar air pada produk perikanan. SNI 01-2354.2-2006. ICS. 67.120.30 Badan Standar Nasional Indonesia. Jakarta.

[BSN] Badan Standardisasi Nasional. 2006. Cara uji kimia bagian 3: Penentuan kadar lemak total pada produk perikanan. SNI 01-2354.3-2006. ICS. 67.120.30 Jakarta(ID): Badan Standardisasi Nasional Indonesia.

[BSN] Badan Standardisasi Nasional. 2009. Batas cemaran mikroba pada produk pangan. SNI 7388:2009. Jakarta(ID): Badan Standardisasi Nasional Indonesia..

[BSN] Badan Standardisasi Nasional. 2009. Batas cemaran logam berat dalam pangan. SNI 7387:2009. Jakarta(ID): Badan Standardisasi Nasional Indonesia.

[BSN] Badan Standardisasi Nasional. 2013. Nugget Ikan. SNI 7758:2013. Jakarta(ID): Badan Standardisasi Nasional Indonesia.

Cilia, Muskita WH, Kurnia A. 2016. Pengaruh penggunaan tepung ikan layang (Decapterus russelli) dengan tepung ikan tongkol (Euthynnus affinis) dalam pakan terhadap pertumbuhan dan tingkat kelangsungan hidup juvenil udang vaname (Litopenaeus vannamei). Jurnal Media Akuatika. 4:177-186.

Direktorat Gizi Depkes RI. 2015. Daftar Komposisi Bahan Makanan. Jakarta.

Direktorat Jenderal Perikanan Tangkap. 2014. Statistik Perikanan Tangkap Indonesia 2013. Kementerian Kelautan dan Perikanan. Jakarta.

Fransiska, Deglas W. 2017. Pengaruh penggunaan tepung ampas tahu terhadap karakteristik kimia dan organoleptik kue stick. Jurnal Teknologi Pangan. 8(2): 171179.

Gagan A. 2010. Kerusakan pangan oleh mikroorganisme.http://anandagagan. blogspot.com/2010/03/ kerusakanpangan-oleh-mikroorganisme.html

Galih. 2014. Sejarah snack stik (online) http:// 
snackkeju.weebly.com/ diakses tanggal 08 januari 2015.

Handarsari E, Syamsianah A, Iii PD, Fikkes G. 2010. Analisis kadar zat gizi, uji cemaran logam dan organoleptik ada bakso dengan substituen ampas tahu. Prosiding Seminar Nasional Unimus. 245-251.

Hanifa R, Hintono A, Pramono YB. 2013. Kadar protein, kadar kalsium dan kesukaan terhadap cita rasa chicken nugget hasil substitusi terigu dengan mocaf dan penambahan tepung tulang rawan. Jurnal Pangan dan Gizi. 4(8):53-54.

Inarest A, Fathonah S, Rosidah. 2014. Pengaruh Penggunaan Jenis Sumber Protein dan Jenis Filler yang Berbeda dalam Pembuatan Nuggets Ampas Tahu. Food Science and Culinary Education Journal. 3(1):56-62.

Ismanto SD, Aisman, Feriviani. 2013. Pengaruh pencampuran tepung ampas tahu dan tepung sagu terhadap mutu nugget ayam. Prosiding Seminar Nasional Peranan Teknologi Pangan dan Gizi dalam Meningkatkan Mutu, Keamanan dan Kehalalan Produk Pangan Lokal (pp. 12-20).

Juhairi MS. 2018. Potensi ampas tahu. Observasi. 2018 Juni 8. Ambon-Maluku, Indonesia

Juanita, sari. 2014. Pengaruh subtitusi tepung mocaf (Modified Cassava Flour) dan penambahan puree wortel (Daucus Carotta L) terhadap sifat organoleptik stick. [Skripsi]. Surabaya (ID). Universitas Negeri Surabaya.

Kaahoao A, Herawati N, Ayu DF. 2017. Pemanfaatan tepung ampas tahu pada pembuatan kukis mengandung minyak sawit merah. Jurnal Online Mahasiswa (JOM) Bidang Pertanian. 4(2):1-15.

Koswara S. 1995. Teknologi Pengolahan Kedelai. Jakarta (ID): Pustaka Sinar Harapan.

Kristiastuti, Afifah. 2010. Pengolahan Kue Nusantara. Surabaya (ID): University Press UNESA.

Lekahena VNJ. 2019. Karakteristik kimia dan sensori produk stik di fortifikasi dengan tepung ikan madidihang. Jurnal Agribisnis Perikanan. 12(2):284-290.
Mahmud DR, Mien K, Zulfianto NA. 2009. Tabel Komposisi Pangan Indonesia. Jakarta (ID): Penerbit Elex Media Komputindo.

Ningrum SO. 2018. Analisis kualitas badan air dan kualitas air sumur di sekitar pabrik gula Rejo Agung Baru kota Madiun. Jurnal Kesehatan Lingkungan. 10(1): 119.

Noonan S, Savage GP. 1999. Oxalate content of food and its effect on humans. Asia Pasific Journal of Clinical Nutrition, 8 (1): 64-74.

Paramita AP, Putri WDR. 2015. Pengaruh penambahan tepung bengkuang dan lama pengukusan terhadap karakteristik fisik, kimia dan organoleptik flake talas. Jurnal Pangan dan Agroindustri, 3(3):1071-1082.

Permadi SN, Mulyani S, Hintono A. 2012. Kadar serat, sifat organoleptik dan rendemen nugget ayam yang disubstitusi dengan jamur tiram putih (Plerotusostreatus). Jurnal Aplikasi Teknologi Pangan. 1(4):115-120.

Pratiwi F. 2013. Pemanfaatan tepung daging ikan layang untuk pembuatan stick ikan. [Skripsi]. Semarang. Fakultas Teknik Universitas Negeri Semarang

Putri VD, Nita Y. 2018. Uji kualitas kimia dan organoleptik nugget ayam hasil substitusi ampas tahu. Jurnal Katalisator. 3(2):143152.

Rifqi. A. 2012. Formulasi nugget tahu pury (Nugget tapury) sebagai alternatif. [skripsi]. Bogor(ID): Institut Pertanian Bogor.

Rosselinda BO, Widanti YA, Mustofa A. 2018. Karakteristik kimia dan sensori nugget ikan ikan Patin (Pangasius sp)-ampas tahu dengan pewarna buah bit (Beta vulgaris). Jurnal Teknologi dan Industri Pangan. 3(1): 49-54.

Sari DI. 2012. Pengaruh substitusi tepung ampas tahu dalam pembuatan nugget terhadap kadar protein dan daya terima konsumen. [Tesis]. Surakarta (ID): Universitas Muhammadiyah Surakarta.

Sefa DS, Agyr SEK. 2004. Chemical Composition and The Effect of Processing An Oxalate Content of Cocoyam Xanthosoma 
sagittifolium and Colocasia esculenta L. Journal of Food Chemistry. 85: 479-487.

Suprapti. 2005 Pembuatan Tahu. Kanisius. Yogyakarta.

Surya C, Ertanto YS, Tomi. 2008. Reaksi mailard pada produk pangan. Diakses pada 28 Juni 2021.

Suter IK. 2013. Pangan fungsional dan prospek pengembangannya. Pentingnya makanan alamiah (Natural Food) untuk Kesehatan Jangka Panjang. Seminar sehari Ikatan Keluarga Mahasiswa (IKM) Jurusan Gizi Politeknik Kesehatan Denpasar, 2013 Agustus 18; Denpasar, Indonesia.

[USDA]. United States Department of Agriculture. 2014. National Nutrient Data Base for Standard. Basic Report 20649, Tapioca, pearl, dry. The national Agriculutural Library

Vaclavik VA, Christian EW. 2014. Essentials of Food Science $4^{\text {th }}$ Edition. New York (US): Spinger

Veni DP, Nita Y. 2018. Uji kualitas kimia dan organoleptik pada nugget ayam hasil substitusi ampas tahu. Jurnal Katalisator. 3(2):135-144.

Wati, Rahma. 2013. Pengaruh penggunaan tepung ampas tahu sebagai bahan komposit terhadap kualitas kue kering lidah kucing. Food Science and Culinary Education Journal 2 (1).

Widiada IGN, Jaya IKS, Sari DYE. 2016. Pengaruh penambahan ikan kembung terhadap organoleptik dan kadar air nugget ampas tahu. Jurnal Gizi Prima. 1(1): 1-5.

Winawanti S. Amrullah, Harmain RM, Dali FA. 2015. Mutu organoleptik dan kimiawi stik rumput laut Kappaphycus alvarezii dengan fortifikasi tepung udang rebon (Mysis sp.).[Skripsi]. Gorontalo(ID): Universitas Negeri Gorontalo.

Yuliana. 2018. Potential and need of products basedoncatfish toimprovenutritionquality of children and community food security. International Proceding, Aptekindo, Surabaya: Universitas Negeri Surabaya. 